\title{
PENERAPAN PSO PADA NAÏVE BAYES UNTUK PREDIKSI HARAPAN HIDUP PASIEN GAGAL JANTUNG
}

\author{
Firza Novaldy ${ }^{1}$, Asti Herliana ${ }^{2}$ \\ 1 Universitas Adhirajasa Reswara Sanjaya \\ e-mail: firza17novaldy@gmail.com \\ ${ }^{2}$ Universitas Adhirajasa Reswara Sanjaya \\ e-mail: asti@ars.ac.id
}

\begin{abstract}
Abstrak
Gagal jantung merupakan masalah kesehatan yang progresif dengan angka mortalitas dan morbiditas yang tinggi di negara maju maupun negara berkembang termasuk Indonesia. Pada tahun 2016, WHO menyebutkan 17,5 juta orang meninggal akibat penyakit kardiovaskular sedangkan pada tahun 2008, penyakit ini mewakili dari 31\% kematian di dunia. Perkiraan akurat dari prognosis gagal jantung sangat penting bagi layanan kesehatan untuk memungkinkan alokasi sumber daya yang tepat kepada dokter dalam membuat keputusan untuk manajemen dan kepada pasien untuk memungkinkan pilihan informasi tentang perawatan dan perawatan akhir kehidupan. Sehingga pada penelitian kali ini dilakukan penerapan metode optimasi Particle Swarm Optimization (PSO) pada algoritma Naïve Bayes sebagai seleksi fitur, yang bertujuan untuk mengetahui nilai akurasi yang dihasilkan oleh algoritma Naïve Bayes dan peran optimasi PSO untuk meningkatkan nilai akurasi dari hasil prediksi harapan hidup pasien gagal jantung. Setelah dilakukan pengujian menggunakan aplikasi Rapidminer dapat diketahui bahwa hasil klasifikasi menggunakan optimasi metode PSO yang mendukung metode Naive Bayes dapat menghasilkan nilai akurasi yang lebih baik, yaitu sebesar $92.67 \%$ dan nilai Area Under ROC (AUC) sebesar 0.908. Hasil akurasi yang didapat pada penelitian kali ini termasuk kedalam kategori Excellent Classification.
\end{abstract}

Kata Kunci: Gagal Jantung, Harapan Hidup, Naive Bayes, Particle Swarm Optimization

\begin{abstract}
Heart failure is a progressive health problem with high mortality and morbidity rates in both developed and developing countries, including Indonesia. In 2016, WHO said 17.5 million people died from cardiovascular disease, whereas in 2008, this disease represented $31 \%$ of deaths in the world. Accurate estimation of the prognosis of heart failure is essential for healthcare services to allow appropriate allocation of resources to physicians in making decisions for management and to patients to allow informed choices about end-of-life care and treatment. So that in this research, the application of the Particle Swarm Optimization (PSO) optimization method on the Naïve Bayes algorithm as a feature selection is carried out, which aims to determine the accuracy value generated by the Naïve Bayes algorithm and the role of PSO optimization to increase the accuracy value of the prediction of life expectancy of failed patients. heart. After testing using the Rapidminer application, it can be seen that the classification results using the PSO optimization method that supports the Naive Bayes method can produce a better accuracy value, which is $92.67 \%$ and the Area Under ROC (AUC) value of 0.908 . The accuracy results obtained in this research are included in the Excellent Classification category.
\end{abstract}

Keywords: Heart Failure, Life expectancy, Naive Bayes, Particle Swarm Optimization. 


\section{Pendahuluan}

Gagal jantung merupakan masalah kesehatan yang progresif dengan angka mortalitas dan morbiditas yang tinggi di negara maju maupun negara berkembang termasuk Indonesia (Siswanto et al., 2015). berdasarkan diagnosis atau gejala, penyakit jantung koroner dan gagal jantung cukup banyak pula ditemukan pada penduduk kelompok umur 15-24 tahun. Kematian akibat penyakit kardiovaskular khususnya gagal jantung adalah $27 \%$. Sekitar $3-20$ per 1000 orang mengalami gagal jantung, angka kejadian gagal jantung meningkat seiring pertambahan usia (100 per 1000 orang pada usia di atas 60 tahun (Astuti \& Suardamana, 2017). Di Indonesia, berdasarkan pada hasil Riset Kesehatan Dasar Badan Penelitian Pengembangan Kesehatan Kementerian Kesehatan RI Tahun 2013, Didapatkan bahwa estimasi penderita gagal jantung berdasarkan diagnosis dokter diperkirakan sebesar $0,13 \%$ atau 229.696 orang dengan estimasi penderita terbanyak berasal dari Provinsi Jawa Timur sebesar 0,19\% atau sekitar 54.826 orang. Sedangkan berdasarkan diagnosis gejala diperkirakan sebesar $0,3 \%$ atau 530.068 orang dengan estimasi jumlah penderita terbanyak berasal dari Provinsi Jawa Barat sebesar 0,3\% atau 96.487 orang (Fikriana, 2018).

Mengingat tingginya angka penderita gagal jantung dan pentingnya organ vital seperti jantung, memprediksikan gagal jantung telah menjadi prioritas bagi dokter, tetapi sampai saat ini meramalkan kejadian terkait gagal jantung dalam praktik klinis biasanya gagal mencapai akurasi tinggi (Chicco \& Jurman, 2020). Sehingga diperlukannya sebuah cara yang tepat untuk mengolah data-data tersebut agar bisa menghasilkan rencana kesehatan yang bisa memprioritaskan upaya manajemen penyakit untuk mengurangi tingkat rawat inap dan kematian pada pasien gagal jantung.

Salah satu cara yang bisa digunakan untuk mengatasi permasalahan tersebut adalah dengan menggunakan teknik data mining. Beberapa teknik data mining telah diterapkan pada dunia kesehatan seperti pada kasus klasifikasi dan data prediktif. Salah satu algoritma klasifikasi dalam data mining yang bisa digunakan adalah Naive Bayes. Naive Bayes menggunakan perhitungan probabilitas matematika dengan syarat bahwa nilai keputusan adalah benar berdasarkan informasi objek (Arifin \& Syalwah, 2020). Keuntungan menggunakan Naive Bayes yaitu metode ini hanya membutuhkan jumlah data pelatihan (Data Training) yang kecil untuk menentukan estimasi parameter yang diperlukan dalam proses pengklasifikasian (Triprasojo et al., 2019). Namun algoritma Naive Bayes perlu dioptimasi lagi dengan cara memberikan bobot pada atribut menggunakan Particle Swarm Optimization (PSO) agar dapat meningkatkan hasil akurasi dan nilai area under cover (AUC) dari penelitian.

Beberapa penelitian tentang penyakit gagal jantung telah dilakukan oleh peneliti sebelumnya namun penelitian yang dilakukan masih mendapatkan nilai akurasi yang belum sempurna. Untuk itu perlu dilakukan penelitian menggunakan algoritma lainnya agar bisa mendapatkan hasil akurasi terbaik. Dalam penelitian Algoritma Klasifikasi Naive Bayes Berbasis Particle Swarm Optimization Untuk Prediksi Penyakit Tuberculosis (Mutiara, 2020). Pada eksperimen pertama hasil akurasi yang didapatkan untuk algoritma Naive Bayes sebesar 92,69\% dengan nilai area under cover (AUC) 0.992. Pada eksperimen kedua dengan menggunakan algoritma Naive Bayes berbasis Particle Swarm Optimization (PSO) hasil akurasi meningkat menjadi $98,72 \%$ dengan nilai area under cover (AUC) 0.999 .

Berikutnya pada penelitian Penerapan Particle Swarm Optimization (PSO) Dalam Pemilihan Atribut Untuk Meningkatkan Akurasi Prediksi Diagnosis Penyakit Hepatitis Dengan Metode Naive Bayes (Koeswara et al., 2020). Dalam perhitungan pertama dihasilkan akurasi untuk algoritma Naive Bayes sebesar $84,85 \%$ dengan nilai AUC 0.894. Dan pada perhitungan kedua setelah menerapkan Particle Swarm Optimization (PSO) pada algoritma Naive Bayes mendapatkan hasil yang meningkat yaitu $92,50 \%$ dengan nilai AUC 0.941. penelitian lain yang menunjukkan bahwa dengan menggunakan PSO memberikan tingkat akurasi yang lebih baik adalah penelitian yang dilakukan dengan menguji data set diabetic retinopathy (Herliana et al., 2018). Pada penelitian ini didapatkan peningkatan hasil akurasi penelitian sebesar $4,35 \%$ menjadi sebesar $76,11 \%$.

Pada penelitian yang berjudul Prediksi Penyakit Ginjal Kronis 
Menggunakan Algoritma Naive Bayes Classifier Berbasis Particle Swarm Optimization (Ariesta \& Arifin, 2019). Hasil dari perhitungan pertama menggunakan algoritma Naive Bayes mendapatkan nilai akurasi sebesar $97.00 \%$. Dan hasil pada perhitungan kedua setelah menerapkan Particle Swarm Optimization (PSO) pada algoritma Naive Bayes mendapatkan nilai akurasi $98.70 \%$.

Berdasarkan latar belakang permasalahan yang telah dibahas, penulis memutuskan untuk melakukan optimasi pada Naive Bayes menggunakan Particle Swarm Optimization (PSO) untuk klasifikasi Heart Failure Clinical Records Dataset yang diperoleh dari University of California Irvine Machine Learning Data Repository.

\section{Metode Penelitian}

Jenis penelitian yang digunakan dalam penelitian ini adalah penelitian eksperimen dengan pendekatan kuantitatif. Pendekatan kuantitatif digunakan karena data yang diperoleh nantinya berupa angka. Penelitian eksperimen digunakan pada penelitian ini untuk menemukan pengaruh dari clinical features terhadap harapan hidup pasien.

Proses untuk melakukan penelitian ini membutuhkan beberapa tahapantahapan yang harus di buat agar peneliti mempunyai arah yang jelas sehingga penelitian bisa dilakukan dengan benar dan mendapatkan hasil yang baik. Adapun beberapa tahapan yang akan dilakukan pada penelitian ini dapat dilihat pada

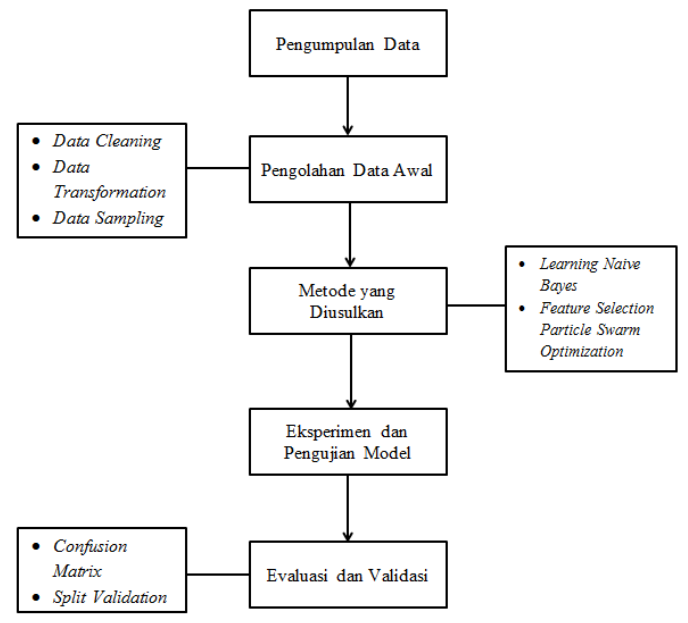

Gambar 1. Tahapan Penelitian

\section{Tahap Pengumpulan Data}

Penelitian ini menggunakan data sekunder yang diperoleh dari halaman situs web University of California Irvine Machine Learning Repository (UCI Repository) yaitu Heart Failure Clinical Records Dataset. Dataset ini terdiri dari 299 data pasien yang mengalami gagal jantung, dikumpulkan selama masa tindak lanjut (follow-up), di mana setiap profil pasien memiliki 13 fitur klinis yang menjadi atribut didalam dataset ini. Dan mempunyai class yang terdiri dari 1 (Death) dan 0 (Survived). Dataset tersebut dapat dilihat pada Tabel 1.

Tabel 1. Deskripsi Atribut Dataset

\begin{tabular}{|c|c|c|}
\hline No. & Nama Atribut & Keterangan \\
\hline 1 & Age & Umur pasien \\
\hline 2 & Anaemia & $\begin{array}{c}\text { Penurunan sel } \\
\text { darah merah atau } \\
\text { hemoglobin }\end{array}$ \\
\hline 3 & $\begin{array}{c}\text { Creatine } \\
\text { phosphokinase } \\
\text { (CPK) }\end{array}$ & $\begin{array}{l}\text { Tingkat enzim } \\
\text { CPK dalam darah }\end{array}$ \\
\hline 4 & Diabetes & Memiliki Diabetes \\
\hline 5 & $\begin{array}{l}\text { Ejection } \\
\text { fraction }\end{array}$ & $\begin{array}{c}\text { Persentase darah } \\
\text { yang } \\
\text { meninggalkan } \\
\text { jantung pada } \\
\text { setiap kontraksi }\end{array}$ \\
\hline 6 & $\begin{array}{l}\text { High blood } \\
\text { pressure }\end{array}$ & $\begin{array}{c}\text { Memiliki } \\
\text { hipertensi }\end{array}$ \\
\hline 7 & Platelets & $\begin{array}{c}\text { Trombosit dalam } \\
\text { darah }\end{array}$ \\
\hline 8 & $\begin{array}{l}\text { Serum } \\
\text { creatine }\end{array}$ & $\begin{array}{c}\text { Tingkat kreatinin } \\
\text { dalam darah }\end{array}$ \\
\hline 9 & Serum sodium & $\begin{array}{l}\text { Tingkat sodium } \\
\text { dalam darah }\end{array}$ \\
\hline 10 & Sex & Jenis kelamin \\
\hline 11 & Smoking & Merokok \\
\hline 12 & Time & $\begin{array}{l}\text { Periode follow-up } \\
\text { pasien }\end{array}$ \\
\hline 13 & Death event & $\begin{array}{l}\text { Jika pasien } \\
\text { meninggal } \\
\text { selama masa } \\
\text { follow-up }\end{array}$ \\
\hline
\end{tabular}




\section{Pengolahan Data Awal}

Pada tahap ini perlu dilakukan eksplorasi atau pendalaman terhadap Heart Failure Clinical Records Dataset. Eksplorasi dilakukan dengan tujuan untuk memastikan semua atribut dan class dalam dataset tersebut valid, sehingga bisa digunakan dalam objek penelitian untuk bisa mengetahui hasil klasifikasi yang terbaik dari Heart Failure Clinical Records Dataset. Tahapan-tahapan yang perlu dilakukan pada Heart Failure Clinical Records Dataset yaitu: (1)Data Cleaning, (2)Data Transformation, (3)Data Sampling.

\section{Model Yang Diusulkan}

Model yang digunakan dalam proses ini merupakan model yang belum pernah digunakan oleh para peneliti sebelumnya pada Heart Failure Clinical Records Dataset ini. Model yang akan digunakan dalam penelitian ini adalah Naïve Bayes dan Particle Swarm Optimization sebagai optimasi. Model yang diusulkan dilakukan dengan tahapan sebagai berikut :

a. Menyiapkan dataset untuk melakukan eksperimen

b. Mendesain arsitektur Naïve Bayes

c. Melakukan training dan testing menggunakan split validation terhadap model Naïve Bayes dan mencatat hasil kinerja dari model

d. Mendesain arsitektur Naïve Bayes dan Particle Swarm Optimization

e. Melakukan training dan testing menggunakan split validation terhadap model Naïve Bayes dan Particle Swarm Optimization kemudian catat hasil kinerja dari model

\section{Eksperimen dan Pengujian Model}

Dalam tahap ini, akan dilakukan eksperimen dan pengujian model. Eksperimen dan pengujian dilakukan menggunakan pemodelan data yang diproses dengan metode yang diusulkan pada penelitian ini. Tools yang digunakan dalam eksperimen ini adalah Rapidminer.

\section{Evaluasi dan Validasi}

Dalam tahap ini, dilakukan evaluasi dari model yang digunakan. Proses evaluasi menggunakan Confusion Matrix dan kurva Receiver Operating Characteristic (ROC). Validasi yang digunakan yaitu Split Validation dengan membagi data training dan data testing. Performa pada model yang digunakan yaitu Naïve Bayes dengan meningkatkan hasil akurasi menggunakan Particle Swarm Optimization. Untuk membandingkan hasil tersebut menggunakan AUC sehingga hasil yang diperoleh lebih akurat.

\section{Hasil dan Pembahasan}

\subsection{Hasil Penelitian}

Penerapan metode Naïve Bayes dan seleksi fitur Particle Swarm Optimization bertujuan untuk mengetahui dan meningkatkan hasil akurasi terhadap Heart Failure Clinical Records Dataset dari penelitian-penelitian yang telah dilakukan sebelumnya. Nilai akurasi akan meningkat atau tidak dapat dilihat pada hasil dari eksperimen. Eksperimen akan dilakukan dengan dua tahap, tahap pertama yaitu eksperimen menggunakan metode Naïve Bayes dan tahap kedua eksperimen menggunakan metode Naïve Bayes dengan Particle Swarm Optimization.

\section{Hasil Eksperimen Menggunakan Naïve Bayes}

Pada tahap ini akan dijelaskan hasil eksperimen menggunakan algoritma Naïve Bayes dengan penerapan teknik Split Validation. Dalam eksperimen ini Dataset yang telah disiapkan untuk diimplementasikan pada uji model algoritma Naïve Bayes dengan teknik evaluasi Split Validation. Setelah dilakukan uji model, maka akan diperoleh hasil seperti pada Tabel 2.

Tabel 2. Hasil Akurasi Model Naïve Bayes Menggunakan Split Validation

\begin{tabular}{|c|c|c|}
\hline Algoritma & $\begin{array}{c}\text { Perbandingan } \\
\text { Split }\end{array}$ & Akurasi \\
\hline Naïve Bayes & $70: 30$ & $74.44 \%$ \\
\hline Naïve Bayes & $\mathbf{8 0 : 2 0}$ & $\mathbf{7 5 . 0 0 \%}$ \\
\hline Naïve Bayes & $90: 10$ & $70.00 \%$ \\
\hline
\end{tabular}

\section{a. Evaluasi Model dengan Confusion Matrix}

Hasil Akurasi yang telah didapatkan menunjukkan bahwa Data Testing yang menggunakan perbandingan split 80:30 merupakan akurasi paling tinggi diantara perbandingan split lainnya. Kemudian Data Testing tersebut dipersiapkan untuk dimasukkan kedalam confusion matrix. Hasil dari confusion matrix dapat dilihat pada tabel 3. 
Tabel 3. Hasil Confusion Matrix Naïve Bayes

\begin{tabular}{|c|c|c|c|}
\hline $\begin{array}{c}\text { Accuracy: } \\
\mathbf{7 5 . 0 0 \%}\end{array}$ & $\begin{array}{c}\text { True } \\
\text { Death }\end{array}$ & $\begin{array}{c}\text { True } \\
\text { Survived }\end{array}$ & $\begin{array}{c}\text { Class } \\
\text { Precision }\end{array}$ \\
\hline Pred.Death & 6 & 2 & $75.00 \%$ \\
\hline Pread.Survived & 13 & 39 & $75.00 \%$ \\
\hline Class recall & $31.58 \%$ & $95.12 \%$ & \multicolumn{1}{|c}{} \\
\hline
\end{tabular}

Dari confusion matrix diatas dapat diukur tingkat akurasi dari klasifikasi sebagai berikut:

$$
\begin{aligned}
& \text { Accuracy }=\quad \mathrm{TP}+\mathrm{TN} \\
& \frac{T P+T N+F P+F N}{6} \times 100 \% \\
& =\frac{6+39}{6+39+2+13} \times 100 \% \\
& \begin{array}{r}
6+39+2+13 \\
\hline
\end{array}
\end{aligned}
$$

b. Evaluasi Model dengan ROC

Selain menghasilkan confusion matrix, pengujian tersebut juga menghasilkan kurva ROC (Receiver Operating Characteristic) yang dapat dilihat pada Gambar 2.

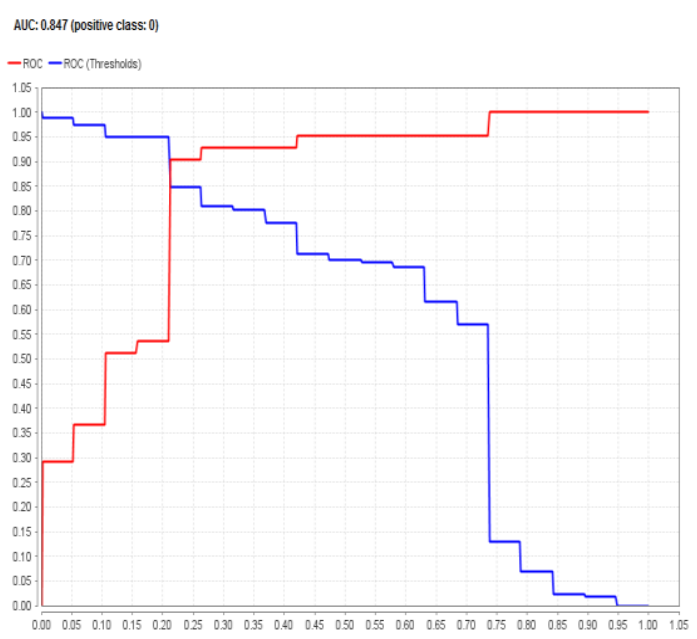

Gambar 2. Nilai AUC Naïve Bayes dalam grafik ROC

Seperti yang terlihat pada Gambar 2. nilai AUC yang didapatkan yaitu sebesar 0.847 dan termasuk kategori Good Classification.

Hasil Eksperimen Menggunakan Naïve Bayes dan Particle Swarm Optimization

Pada tahap ini akan dilakukan eksperimen menggunakan Particle Swarm Optimization sebagai seleksi fitur sehingga terjadi pemilihan bobot yang bagus dan relevan yang dimaksudkan untuk meningkatkan nilai akurasi. Hasil dari pembobotan oleh PSO dapat dilihat pada Tabel 4.

Tabel 4. Hasil Pembobotan PSO

\begin{tabular}{|c|c|}
\hline attribute & weight \\
\hline age & 1 \\
\hline anaemia & 1 \\
\hline creatine_phosphokinase & 0 \\
\hline diabetes & 0.917 \\
\hline ejection_fraction & 0.372 \\
\hline high_blood_pressure & 0.974 \\
\hline platelets & 0 \\
\hline serum_creatine & 0 \\
\hline serum_sodium & 1 \\
\hline sex & 0.287 \\
\hline smoking & 1 \\
\hline time & 0.010 \\
\hline
\end{tabular}

Hasil dari seleksi atribut ini memperoleh 3 atribut terendah yaitu dengan weight 0 pada atribut creatine phosphokinase, serum creatinine dan serum sodium yang berarti bahwa atribut tersebut tidak memiliki pengaruh apapun terhadap nilai akurasi yang didapatkan. Sehingga jika dua atribut tersebut dihilangkan, dapat diperoleh 9 atribut yang bisa digunakan untuk mempengaruhi hasil akurasi dari klasifikasi Heart Failure Clinical Records Dataset karena mempunyai bobot diatas 0 .

\section{a. Evaluasi Model dengan Confusion Matrix}

Setelah dilakukan pembobotan menggunakan PSO data yang telah dipersiapkan tersebut dimasukkan kedalam confusion matrix. Hasil dari confusion matrix dapat dilihat pada tabel 5 .

Tabel 5. Hasil Confusion Matrix Naïve Bayes dan PSO

\begin{tabular}{|c|c|c|c|}
\hline $\begin{array}{c}\text { Accuracy: } \\
\mathbf{9 1 . 6 7 \%}\end{array}$ & $\begin{array}{c}\text { True } \\
\text { Death }\end{array}$ & $\begin{array}{c}\text { True } \\
\text { Survived }\end{array}$ & $\begin{array}{c}\text { Class } \\
\text { Precision }\end{array}$ \\
\hline Pred.Death & 16 & 2 & $88.89 \%$ \\
\hline Pread.Survived & 3 & 39 & $92.86 \%$ \\
\hline Class recall & $84.21 \%$ & $95.12 \%$ & \\
\hline
\end{tabular}


Dari confusion matrix diatas dapat diukur tingkat akurasi dari klasifikasi sebagai berikut:

$$
\begin{aligned}
\text { Accuracy } & =\frac{\mathrm{TP}+\mathrm{TN}}{\mathrm{TP}+\mathrm{TN}+\mathrm{FP}+\mathrm{FN}} \times 100 \% \\
& =\frac{16+39}{16+39+2+3} \times 100 \% \\
& 91.67 \%
\end{aligned}
$$

\section{b. Evaluasi Model dengan ROC} Pengujian Tersebut juga menghasilkan kurva ROC (Receiver Operating Characteristic) seperti pada Gambar 3.

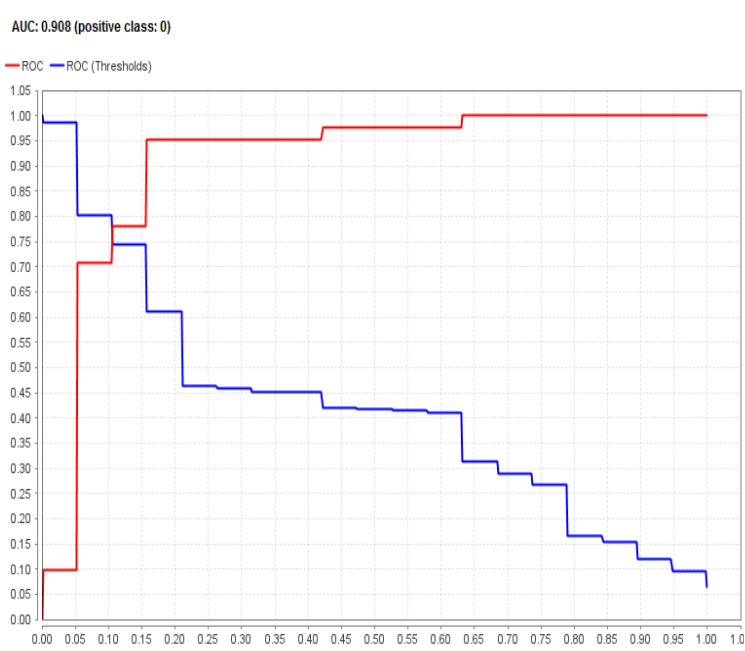

Gambar 3. Nilai AUC Naïve Bayes dan PSO dalam grafik ROC

seperti pada Gambar 3. dengan nilai AUC sebesar 0.908 dan termasuk kategori Excellent Classification.

\subsection{Pembahasan}

Berdasarkan hasil dari penelitian di atas, dalam tahap ini akan dilakukan evaluasi untuk mengetahui peningkatan nilai akurasi dari pengujian klasifikasi menggunakan metode Naïve Bayes sebelum dilakukan seleksi fitur dan Naïve Bayes setelah seleksi fitur menggunakan Particle Swarm Optimization dengan cara menghitung jumlah data testing dengan benar dalam bentuk nilai akurasi dan grafik ROC. Berikut ini merupakan perbandingan nilai akurasi dan ROC pada algoritma Naïve Bayes sebelum dilakukan seleksi fitur dan setelah seleksi fitur dengan Particle Swarm Optimization yang dapat dilihat pada Tabel 6 dan Gambar 4.
Tabel 6. Perbandingan Hasil Accuracy dan

\begin{tabular}{|c|c|c|c|}
\hline No. & Metode & Accuracy & ROC \\
\hline 1 & Naive Bayes & $75.00 \%$ & 0.847 \\
\hline 2 & $\begin{array}{c}\text { Naive Bayes }+ \\
\text { Particle } \\
\text { Swarm } \\
\text { Optimization }\end{array}$ & $91.67 \%$ & 0.908 \\
\hline
\end{tabular}

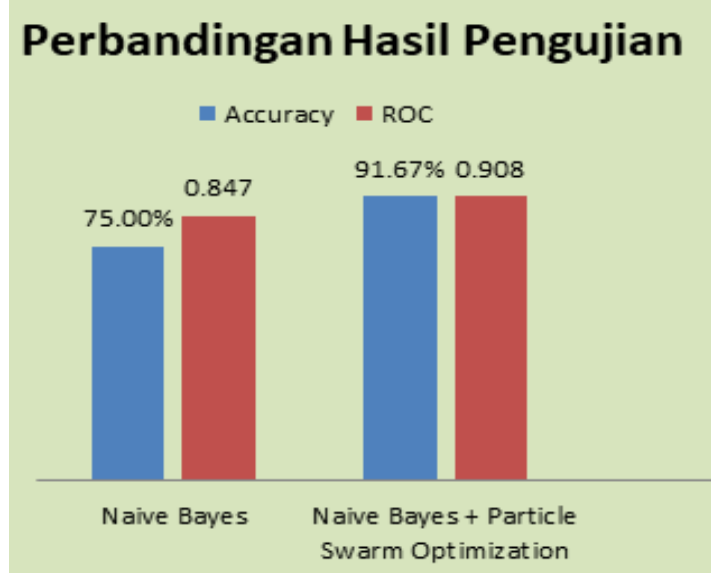

Gambar 4. Perbandingan Hasil Pengujian

Pada Gambar 4 dapat dilihat bahwa hasil klasifikasi Naïve Bayes mengalami peningkatan nilai akurasi sebesar 16,67\% setelah dilakukan seleksi fitur menggunakan Particle Swarm Optimization. Sehingga dapat dibuktikan bahwa penggunaan seleksi fitur Particle Swarm Optimization dapat meningkatkan nilai akurasi dari metode Naïve Bayes pada klasifikasi penyakit gagal jantung.

\section{Kesimpulan}

Pada penelitian ini telah dilakukan eksperimen klasifikasi data mining menggunakan algoritma Naive Bayes dan optimasi menggunakan Particle Swarm Optimization pada Naive Bayes. Eksperimen dilakukan pada data yang diperoleh dari UCI Repository yaitu Heart Failure Clinical Records Dataset. Untuk mencari hasil yang optimal dan bagus dari klasifikasi, maka pada penelitian ini digunakan metode Split Validation untuk validasi peforma klasifikasi. Adapun kesimpulan dari hasil penelitian ini yaitu:

1. Hasil dari perhitungan dengan algortima Naive Bayes yang diterapkan pada Heart Failure Clinical Records Dataset mendapatkan nilai akurasi confusion 
matrix sebesar $75.00 \%$ dan AUC sebesar 0.847. Kemudian setelah diterapkan Particle Swarm Optimization untuk seleksi fitur pada dataset yang digunakan, Nilai akurasi meningkat menjadi $91.67 \%$ dan AUC sebesar 0.908 .

2. Hasil dari uji coba menggunakan optimasi Particle Swarm Optimization pada algoritma Naive Bayes diperoleh beberapa atribut-atribut yang berpengaruh terhadap bobot atribut, yang bisa digunakan untuk mempengaruhi hasil akurasi dari klasifikasi Heart Failure Clinical Records Dataset karena mempunyai bobot diatas 0 yaitu atribut age, anaemia, diabetes, ejection fraction, high blood pressure, serum sodium, sex, smoking, time. Sehingga dapat disimpulkan bahwa menggunakan Particle Swarm Optimization dapat meningkatkan hasil akurasi dari algoritma Naive Bayes pada Heart Failure Clinical Records Dataset.

Berdasarkan hasil dari penelitian yang telah dilakukan, maka peneliti mengajukan saran untuk penelitian selanjutnya sebagai berikut :

1. Pada penelitian selanjutnya bisa dilakukan eksperimen pada Heart Failure Clinical Records Dataset dengan menggunakan metode algoritma data mining dan metode optimasi yang lainnya yang belum digunakan untuk dataset ini seperti teknik reduksi dimensi dan algortima genetika untuk dapat mengetahui peforma yang dihasilkan oleh algoritma lain dalam mengklasifikasi Heart Failure Clinical Records Dataset.

2. Pada penelitian berikutnya dapat dilakukan eksperimen menggunakan optimasi Particle Swarm Optimization pada metode algoritma Naive Bayes terhadap dataset lainnya yang lebih beragam untuk mengetahui peforma yang dapat dihasilkan oleh metode tersebut.

\section{Referensi}

Ariesta, D., \& Arifin, T. (2019). Prediksi Penyakit Ginjal Kronis Menggunakan
Naïve Bayes Classifier Berbasis Particle Swarm Optimization. Jurnal Tekno Insentif, 13, 26-30. https://doi.org/10.36787/jti.v13i1.97

Arifin, T., \& Syalwah, S. (2020). Prediksi Keberhasilan Immunotherapy Pada Penyakit Kutil Dengan Menggunakan Algoritma Naïve Bayes. Jurnal Responsif, 2(1), 38-43.

Astuti, D. P. T., \& Suardamana, I. K. (2017). Gagal jantung. Universitas Udayana, 1-2.

Chicco, D., \& Jurman, G. (2020). Machine learning can predict survival of patients with heart failure from serum creatinine and ejection fraction alone. $B M C$ Medical Informatics and Decision Making, 20(1), 1-16. https://doi.org/10.1186/s12911-0201023-5

Fikriana, R. (2018). Sistem Kardiovaskuler (Cetakan 1, Issue Juni). deepublish.

Herliana, A., Arifin, T., Susanti, S., \& Hikmah, A. B. "Feature Selection of Diabetic Retinopathy Disease Using Particle Swarm Optimization and Neural Network," 2018 6th International Conference on Cyber and IT Service Management (CITSM), Parapat, Indonesia, 2018, pp. 1-4, doi: 10.1109/CITSM.2018.8674295.

Koeswara, T. S. N., Mardiyanto, M. S., \& Ghani, M. A. (2020). Penerapan Particle Swarm Optimization (Pso) Dalam Pemilihan Atribut Untuk Meningkatkan Akurasi Prediksi Diagnosispenyakit Hepatitis Dengan Metode Naive Bayes. Journal SpeedSentra Penelitian Engineering Dan Edukasi, 12(1), 1-10.

Mutiara, E. (2020). Algoritma Klasifikasi Naive Bayes Berbasis Particle Swarm Optimization Untuk Prediksi Penyakit Tuberculosis ( TB ). 8(1), 46-58.

Siswanto, B. B., Hersunarti, N., Erwinanto, R. B., Pratikto, R. S., Nauli, S. E., \& Lubis, A. C. (2015). Pedoman Tatalaksana Gagal Jantung (Edisi Pert). PERKI.

Triprasojo, A., Mauliana, P., \& Wiguna, W. (2019). Penerapan Algoritma Naive Bayes Untuk Klasifikasi Deteksi Mesothelioma. JURNAL INFORMATIKA, 1-8. 